MaPan : Jurnal Matematika dan Pembelajaran

p-ISSN: 2354-6883 ; e-ISSN: 2581-172X

Volume 8, No 1, June 2020 (49-60)

DOI: https://doi.org/10.24252/mapan.2020v8n1a4

\title{
PROBLEM-BASED LEARNING WITH A SCIENTIFIC APPROACH AS A SOLUTION TO DEVELOP STUDENTS' MATHEMATICS LEARNING OUTCOMES
}

\author{
A. Riska Atika1), Ridwan Idris²), Andi Ika Prasasti Abrar'3), Ahmad Farham Majid4) \\ 1,2,3,4Program Studi Pendidikan Matematika, UIN Alauddin Makassar \\ 1,2,3,4Jl. H. M. Yasin Limpo Nomor 36 Samata-Gowa \\ E-mail: riskaatikaaaa@gmail.com ${ }^{1)}$, ridwanidris34@ gmail.com²), \\ ika.prasastiabrar@uin-alauddin.ac.id3), ahmad.farham@uin-alauddin.ac.id4)
}

Received April 20, 2020; Revised June 14, 2020; Accepted June 16, 2020

\begin{abstract}
:
This study aims to understand the influence of the problem-based learning model with a scientific approach to grade VIII students' mathematics learning outcomes at SMP Negeri 1 Sungguminasa. This research uses a quasi-experimental method with a nonequivalent control group design. This research collected its research data through the distribution of observation sheets and learning achievement tests. Based on the descriptive statistical analysis results that the average value of student learning outcomes by using the problem-based learning model is 78.7, and the standard deviation is 7.21, while the average value of student learning outcomes without the problem-based learning model treatment is 72.19 , and the standard deviation is 7.01 . The results of the inferential analysis indicate the significant value (2-tailed) of $0.003<$ 0.05 , signifying a rejected $\mathrm{H}_{0}$. For that reason, this research concludes that there is a significant difference in grade VIII students' mathematics learning outcomes at SMP Negeri 1 Sungguminasa when the problem-based learning model with a scientific approach is implemented.
\end{abstract}

Keywords: Learning Outcomes, Problem Based Learning (PBL), Scientific Approach

\section{MODEL PEMBELAJARAN BERBASIS MASALAH DENGAN PENDEKATAN SAINTIFIK SEBAGAI SOLUSI DALAM MENINGKATKAN HASIL BELAJAR MATEMATIKA SISWA}

\begin{abstract}
Abstrak:
Penelitian ini bertujuan untuk mengetahui pengaruh model pembelajaraan berbasis masalah dengan pendekatan saintifik terhadap hasil belajar matematika siswa kelas VIII SMP Negeri 1 Sungguminasa. Jenis penelitian yang digunakan adalah quasi eksperimen dengan desain penelitian non equivalent control group design. Instrumen yang digunakan adalah lembar observasi dan tes hasil belajar. Berdasarkan hasil analisis deskriptif menunjukkan bahwa nilai rata-rata hasil belajar siswa menggunakan model problem based learning adalah sebesar 78,7, dan standar deviasinya 7,21, sedangkan rata-rata hasil belajar siswa yang tidak menggunakan model problem based learning adalah 72,19, dan standar deviasinya 7,01. Hasil analisis inferensial menunjukkan nilai signifikan (2-tailed) sebesar 0,003 < 0,05, yang berarti $\mathrm{H}_{0}$ ditolak.
\end{abstract}


Dapat disimpulkan bahwa terdapat perbedaan dalam hasil belajar matematika siswa kelas VIII di SMP Negeri 1 Sungguminasa ketika menerapkan model pembelajaran berbasis masalah dengan pendekatan saintifik.

Kata Kunci: Hasil Belajar, Pembelajaran Berbasis Masalah, Pendekatan Saintifik

How to Cite: Atika, A. R., Idris, R., Abrar, A. I. P., \& Majid, A. F. (2020). Problem-Based Learning with A Scientific Approach as A Solution to Develop Students' Mathematics Learning Outcomes. MaPan: Jurnal Matematika dan Pembelajaran, 8(1), 49-60. https://doi.org/10.24252/mapan.2020v8n1a4.

\section{INTRODUCTION}

$\mathrm{E}$ ducation is all experiences that take place in the environment and throughout human life. Education for human life is an absolute necessity that must be fulfilled throughout life (Kadir, 2015). Education has an important role in society because through education; it has knowledge, skills, and attitudes so that it can develop itself and become a person who has good character (Untayana \& Harta, 2016).

In improving the quality of education in Indonesia, the government has made efforts through improvements such as the curriculum. Based on the National Education System, the curriculum is a set of plans and arrangements regarding the objectives, materials, or teaching materials, as well as the methods or methods used as guidelines for organizing learning activities to achieve educational goals. In other words, the curriculum is a teacher's guide in organizing learning activities (Nuralam \& Eliyana, 2017). The 2013 curriculum is a curriculum that is expected to be a refinement of the KTSP curriculum. The most fundamental characteristic of the 2013 curriculum at present is to demand that teachers be knowledgeable as much as possible while students are encouraged to have responsibility for the environment, interpersonal and interpersonal skills, and have critical thinking skills (Ibrahim, 2014).

One factor that can help students learn mathematics is the teacher, who can use a method to attract students' attention so that they can increase the intensity of learning mathematics independently (Fadliah, 2018). The 2013 curriculum is a curriculum that applies the learning process using a scientific approach (scientific approach). Learning in the 2013 curriculum is applied in general with four models, namely Discovery, Inquiry, Problem-Based Learning, and Project-Based Learning. The application of the 2013 learning model aims to enable students to independently learn so that the learning process that is 
running is no longer teacher-centered (Hardiyanti, Wardani, \& Nurhayati, 2017).

A scientific approach is a learning approach that provides opportunities for students to broadly explore and elaborate on the material they are learning (Rusman, 2015). The scientific approach is expected to create a learning process that can actively contain concepts, laws, and principles through the stages of observing, formulating a problem, formulating a hypothesis, collecting data with a variety of suitable techniques, analyzing data, drawing conclusions, and communicating concepts (Mustami \& Irwansyah, 2015).

Based on the observations of researchers at SMPN 1 Sungguminasa who have implemented the 2013 curriculum, the learning process is still teachercentered, so students tend to be less active in learning. This affects student learning outcomes. In the interview results of researchers on Class VIII students at SMPN 1 Sungguminasa obtained information that mathematics is a difficult subject. While the results of the interview with one of the mathematics teachers that mathematics learning outcomes in the class are still relatively low. Mathematics KKM scores are 75. The low mathematics scores of these students can be caused by internal and external factors. Internal factors such as motivation, physical condition, and others, while external factors are in the form of learning processes that take place in the classroom, the learning process in the class is still less varied and still leads to teacher-centered.

Ariani (2017) explained that problem-based learning is a directly related learning model characterized by student-centered and able to increase mathematical intelligence; in this case, the ability to learn mathematics. Problem Based Learning as a model gives freedom of thought and skill in solving problems to the students in the learning process by using a real problem (Sari, Wahyudi, \& Hendrias, 2017). The results of the study conducted by Kaharuddin (2019) about the effect of the problem-based learning model on mathematic learning outcomes concluded that the application of a problem-based learning model has a positive effect on mathematics learning outcomes. Similar research was also conducted by Khoiriyah \& Husamah (2018) about problem-based learning that creative thinking skills, problem-solving skills, and learning outcome of seventh-grade students with the conclusion that the application of PBL improves (1) the average of creative thinking skill was $11 \%$, and the completion rate of $17.5 \%$; (2) the average of problem-solving skills knowledge was $27 \%$ and the completion of $47 \%$; and (3) the average score of learning outcomes was $3 \%$ and the completion rate was $15 \%$. 
This problem-based learning model is a learning strategy that involves students to solve a problem through the stages of scientific methods so that students can learn knowledge related to the problem and make students skilled in solving a problem (Ali \& Evi, 2016). Problems that are solved are directly related to real-life; this can increase students' motivation and interest in the material being studied (Illahi, 2018). This is in line with the results of research conducted by Rukmana, Jalmo, \& Yolida (2013).

From several relevant theoretical and research studies that have been described previously, it can be concluded that the application of problem-based learning model can improve learning outcomes through the learning process. Based on the description above, to improve student learning outcomes, it is necessary to research to see the effect of problem-based learning as a solution to develop students' mathematics learning outcomes.

\section{RESEARCH METHOD}

The approach used in this study is a quantitative research approach. This type of research used in this study is quasi-experimental research or so-called quasi-experimental. The design that is used in this study is a non-equivalent control group design. This design consists of two groups, one group that is given treatment and the other group that is not treated. The experimental group and the control group are given a pre-test, then the experimental group is given treatment, and finally, both are given a post-test (Emzir, 2015). The design can be seen in Table 1 (Sugiyono, 2015).

Table 1. Research Design

\begin{tabular}{cccc}
\hline Group & Pre-Test & Treatment & Post-Test \\
\hline Experimental & $\mathrm{T} 1$ & $\mathrm{X}$ & $\mathrm{T} 2$ \\
Control & $\mathrm{T} 1$ & $\mathrm{Y}$ & $\mathrm{T} 2$ \\
\hline
\end{tabular}

Note:

$\mathrm{X}=$ Problem-based learning model with a scientific approach

$\mathrm{Y}=$ Conventional model

$\mathrm{T} 1=$ Pre-Test Results of experimental and control classes

$\mathrm{T} 2=$ Post-Test Results of experimental and control classes

The population is defined as the whole object, which is an aspect of the characteristics, phenomena, and concepts that are the center of research (Irianto, 2010). The population in this study is all students of Grade VIII at SMP Negeri 
1 Sungguminasa, Gowa Regency, in the academic year 2019-2020. The total population is 391 people spread out in 11 classes (classes VIII.A-VIII.K). The sampling technique in this study is simple random sampling.

The instrument used in this study is the observation sheet and test in the form of essay questions. The observation sheet is used to observe the implementation of learning done by researchers and observed by two observers. A test is an information-gathering tool that is more official than other tools because it is full of limitations (Arikunto, 2010). Learning outcomes are changes that occur in students, both relating to cognitive, affective, and psychomotor aspects as a result of learning activities (Susanto, 2013).

Sources of data in this study are class VIII.D and VIII.I. Class VIII.D as an experimental class and class VIII.I as a control class. Data collection techniques used in the form of written tests and observation sheets. Data analysis techniques use descriptive statistical analysis and inferential statistical analysis techniques. Descriptive statistical analysis is to find out the mean, median, minimum value, maximum value, and standard deviation, while the inferential statistics used are the normality test, homogeneity test, and hypothesis testing.

\section{RESULTS AND DISCUSSION}

Description of student learning outcomes in mathematics taught by using the Problem-Based Learning model with a scientific approach to grade VIII students of SMP Negeri 1 Sungguminasa

Mathematical learning outcomes data of experimental class students who were taught using a model of problem-based learning with a scientific approach before and after being given different treatment from the control class is obtained. Table 2 is a descriptive analysis result of the mathematics learning outcomes of experimental class students.

Table 2. Statistics Description of Mathematics Learning Outcomes Experimental Class

\begin{tabular}{ccc}
\hline Statistics & \multicolumn{2}{c}{ Statistical Value } \\
\cline { 2 - 3 } & Pre-test & Post-test \\
Lowest score & 30 & 67 \\
Highest score & 60 & 90 \\
Average (x) & 41.93 & 78.7 \\
Standard Deviation & 9.5 & 7.21 \\
$(\mathrm{SD})$ & & \\
\hline
\end{tabular}


From table 2, student learning outcomes using the model of problembased learning with a scientific approach obtained an average pre-test of 41.93 and a standard deviation of 9.5. While the average post-test score obtained is 78.7, and the standard deviation is 7.21.

If student learning outcomes are grouped into four categories of learning outcomes such as low, medium, high, and very high, then the post-test frequency and the pre-test frequency will be obtained in Table 3.

Table 3. Category of Mathematics Learning Outcomes Experiment Class

\begin{tabular}{cccccc}
\hline $\begin{array}{c}\text { Mastery } \\
\text { Level }\end{array}$ & Category & \multicolumn{2}{c}{$\begin{array}{c}\text { Pre-test Class } \\
\text { Experiment }\end{array}$} & \multicolumn{2}{c}{$\begin{array}{c}\text { Post-test Class } \\
\text { Experiment }\end{array}$} \\
\cline { 3 - 6 } & & Frequency & Percentage & Frequency & Percentage \\
$21-40$ & Low & 18 & $51.4286 \%$ & - & - \\
$41-60$ & Medium & 17 & $48.5714 \%$ & - & - \\
$61-80$ & High & - & - & 24 & $68.5714 \%$ \\
$81-100$ & Very & - & - & 11 & $31.4286 \%$ \\
& High & & & & 100 \\
\hline
\end{tabular}

Based on the analysis of descriptive statistics that have been done, it can be seen that the mathematics learning outcomes of the experimental class students of the pre-test are in a low category or around $51.4286 \%$ while the learning outcomes of the experimental class students of the post-test is in the high category or around $68.5714 \%$.

According to the researcher analysis, before applying the problem-based learning model with a scientific approach, the category of student learning outcomes is in a low category. Most students still have difficulty writing down information and problems contained in a problem, difficulty expressing daily events into the language of mathematics and there are still some students who just simply calculate the numbers without knowing the meaning of the problem or without knowing the meaning of each step in solving the problem.

After applying the problem-based learning model with a scientific approach, the category of student ability is in the high category. It is because by using the problem-based learning model, students are given problems and then solve them themselves. According to Duch (Amiluddin \& Sugiman, 2016; Rusman, 2015), problem-based learning is a learning model that starts by asking problems, questions, which makes students want to solve them. Students are 
very enthusiastic at every stage of learning that is done. Students are also more active in solving mathematical problems with their respective groups, and they can exchange opinions with their peers, which makes them more comfortable, more free, giving opinions, and input to mathematical problems that are they do it in the learning process in class.

Based on the above theory, it can be concluded that there are differences in average mathematics learning outcomes of students who are taught using the problem-based learning model with a scientific approach in grade VIII students of SMP Negeri 1 Sungguminasa before being treated and after being given treatment in the class.

Description of mathematics learning outcomes of students who are not taught using the Problem-Based Learning model with a scientific approach to grade VIII students of SMP Negeri 1 Sungguminasa

Mathematical learning outcomes data of control class students who were taught using a conventional model is obtained. Table 4 is a descriptive analysis result of the mathematics learning outcomes of control class students.

Table 4. Statistics Description of Mathematics Learning Outcomes Control Class

\begin{tabular}{ccc}
\hline Statistics & \multicolumn{2}{c}{ Statistical Value } \\
\cline { 2 - 3 } & Pre-test & Post-test \\
Lowest score & 25 & 62 \\
Highest score & 60 & 85 \\
Average (x) & 41.21 & 72.19 \\
Standard Deviation & 10.01 & 7.01 \\
$(\mathrm{SD})$ & & \\
\hline
\end{tabular}

From table 4, students learning outcomes who are not taught using the problem-based learning model with a scientific approach obtained an average pre-test of 41.21 and a standard deviation of 10.01 while the average post-test score obtained is 72.19 , and the standard deviation is 7.01 .

If student learning outcomes are grouped into four categories of learning outcomes such as low, medium, high, and very high, then the post-test frequency and the pre-test frequency will be obtained in table 5 . 
Table 5. Category of Mathematics Learning Outcomes Control Class

\begin{tabular}{|c|c|c|c|c|c|}
\hline \multirow[t]{2}{*}{$\begin{array}{c}\text { Mastery } \\
\text { Level }\end{array}$} & \multirow[t]{2}{*}{$\begin{array}{c}\text { Categor } \\
\mathbf{y}\end{array}$} & \multicolumn{2}{|c|}{$\begin{array}{c}\text { Pre-test Class } \\
\text { Control }\end{array}$} & \multicolumn{2}{|c|}{$\begin{array}{c}\text { Post-test Class } \\
\text { Control }\end{array}$} \\
\hline & & $\begin{array}{c}\text { Frequenc } \\
y\end{array}$ & $\begin{array}{c}\text { Percentag } \\
\text { e }\end{array}$ & $\begin{array}{c}\text { Frequenc } \\
y\end{array}$ & $\begin{array}{c}\text { Percentag } \\
\text { e }\end{array}$ \\
\hline $21-40$ & Low & 16 & $45.7143 \%$ & - & - \\
\hline $41-60$ & Medium & 19 & $54.2857 \%$ & - & - \\
\hline $61-80$ & High & - & - & 29 & $82.8571 \%$ \\
\hline $81-100$ & $\begin{array}{l}\text { Very } \\
\text { High }\end{array}$ & - & - & 6 & $17.1429 \%$ \\
\hline \multicolumn{2}{|c|}{ Total } & 35 & 100 & 35 & 100 \\
\hline
\end{tabular}

Based on the analysis of descriptive statistical data that the average mathematics learning outcomes of students in the control class are in the medium category with a percentage of $54.2857 \%$. This happens because most students still have difficulty in answering the questions given; students have not relearned the material they have learned and did not do the assignments.

According to the analysis of researchers in the control class that the values obtained by students who are taught not using the problem-based learning model have activities in the learning process that tend to be less active unlike in the experimental class, students tend to be active. The research conducted Paloloang (2014) about the application of problem-based learning models to improve student learning outcomes showing that during the learning process in the classroom without using the problem-based learning model, students rarely ask questions or answer questions from the teacher, students are less active in following the lessons. The students' activeness is very good in the teaching and learning process in the experimental class as well as doing assigned tasks and is active in questioning things that he does not know. Before applying the problem-based learning model with a scientific approach, most students still had difficulty in writing information and problems contained in a problem, difficulties in expressing daily events in the language of mathematics, and there were still some students who only simply calculated the numbers without knowing the purpose of the problem or without knowing the meaning of each step in solving the problem.

Based on the description above, it can be concluded that the learning outcomes of students using the conventional model are not the same as student 
learning outcomes using the problem-based learning model with a scientific approach.

The difference in mathematics outcomes of grade VIII students of SMP Negeri 1 Sungguminasa uses a model of learning Problem-Based Learning with a scientific approach to the conventional model

Based on data analysis, after the data is known that the research results are normally distributed and homogeneous, it is continued by testing the difference in the average of the experimental class and the control class using the independent sample t-test. An independent sample t-test analysis is used to determine whether the $\mathrm{H}_{0}$ hypothesis is rejected or accepted. The inferential analysis shows that the significant value (2-tailed) of $0.003<0.05$. Based on the results of the analysis, it can be concluded that there are differences in the average student learning outcomes between the problem-based learning (PBL) model with a scientific approach with the conventional model in grade VIII students of SMP Negeri 1 Sungguminasa, so $\mathrm{H}_{0}$ is rejected.

Based on observation made during the learning process in the experimental and control class, students are more active in the experimental class using the problem-based learning model with a scientific approach compared to the control class. This is supported by the results of research conducted by Farhan \& Retnawati (2014) about the effectiveness of problembased learning that the average value of problem-based learning is higher than conventional learning or, in other words, that problem-based learning is more effective than conventional model towards learning achievement.

It can be concluded that there are differences in student learning outcomes using the problem-based learning model with a scientific approach.

The effect of Problem-Based Learning model with scientific approaches and conventional models on mathematics learning outcomes of grade VIII students of SMP Negeri 1 Sungguminasa

Based on the independent sample t-test $\mathrm{H}_{0}$ test is rejected which means there are differences in the average student learning outcomes between the problem-based learning (PBL) learning model with a scientific approach to the conventional model in grade VIII students of SMP Negeri 1 Sungguminasa. If there is a difference in the average student learning outcomes, there is an influence on student mathematics learning outcomes.

This is in line with previous research conducted by Mulyanto, Gunarhadi, \& Indriayu (2018) "The effect of problem-based learning model on student mathematics learning outcomes viewed from critical thinking skills" 
This study aims to determine the effect of applying problem-based learning model on students' mathematics learning outcomes viewed from critical thinking skills of fifth-grade students of the private primary school in the Surakarta region.

Based on the previous analysis in the experimental class shows that the students learning outcomes who are taught to use the problem-based learning model with a scientific approach influence the mathematics learning outcomes of students than those who are taught not using the problem-based learning model with a scientific approach. This happens because students who are taught by using a model of problem-based learning with a scientific approach have learning activities that are more active and enthusiastic than those taught not to use problem-based learning with the scientific approach itself. Students are enthusiastic at every stage of learning undertaken. Students also more active in solving mathematical problems with their respective groups, and they can exchange opinions with friends.

Based on the above discussion and the support of the relevant studies, it can be concluded that there is an influence of the problem-based learning model with a scientific approach to the mathematics learning outcomes of grade VIII students of SMP Negeri 1 Sungguminasa.

\section{CONCLUSION}

Based on the results and discussions, the following conclusions are obtained that 1) student learning outcomes using the problem-based learning model with a scientific approach obtained an average pre-test of 41.93 and a standard deviation of 9.5. While the average post-test score obtained is 78.7 , and the standard deviation is 7.21. So, a problem-based learning model with a scientific approach can improve mathematics learning outcomes of grade VIII students of SMPN 1 Sungguminasa; 2) student learning outcomes using conventional learning models obtained an average pre-test of 41.21 and a standard deviation of 10.01. while the average post-test score obtained is 72.19, and the standard deviation is 7.01. So, the students learning outcomes using problem-based learning model with a scientific approach are not the same as the student learning outcomes using the conventional model; 3) there are differences in average student learning outcomes between the problem-based learning model with the scientific approach and the conventional model in grade VIII students of SMPN 1 Sungguminasa; 4) there is an influence of the 
problem-based learning model with a scientific approach to the mathematics learning outcomes of grade VIII students of SMPN 1 Sungguminasa.

\section{REFERENCES}

Amiluddin, R., \& Sugiman, S. (2016). Pengaruh problem posing dan PBL terhadap prestasi belajar dan motivasi belajar mahasiswa pendidikan matematika. Jurnal Riset Pendidikan Matematika, 3(1), 100-108. https:/ / doi.org/10.21831/jrpm.v3i1.7303.

Ariani, D. N. (2017). Pengaruh model pembelajaran berbasis masalah dengan pendekatan saintifik terhadap kemampuan berfikir kritis matematis mahasiswa/I PGMI, Muallimuna : Jurnal Madrasah Ibtidaiyah, 3(2), 108115. http:/ / doi.org/10.31602/muallimuna.v3i2.1214.

Arikunto, S. (2010). Dasar-dasar evaluasi pendidikan edisi revisi, Cet. 5. Jakarta: PT. Bumi Aksara.

Emzir. (2015). Metodologi penelitian pendidikan kuantitatif dan kualitatif. Jakarta: Rajawali Pers.

Fadliah, H. (2018). Perbandingan keefektifan penggunaan alat peraga pada model pembelajaraan kooperatif tipe think pair share (TPS) dengan pembelajaran kooperatif tipe jigsaw terhadap hasil belajar matematika siswa kelas VII MTs. Guppi Samata Kabupaten Gowa. Thesis. Universitas Islam Negeri Alauddin Makassar. Retrieved from http:/ / repositori.uinalauddin.ac.id/view/ divisions/pm/2018.html.

Farhan, M., \& Retnawati, H. (2014). Keefektifan PBL dan IBL ditinjau dari prestasi belajar, kemampuan representasi matematis, dan motivasi belajar. Jurnal Riset Pendidikan Matematika, 1(2), 227-240. https:/ / doi.org/ 10.21831/jrpm.v1i2.2678.

Hardiyanti, P. C., Wardani, S., \& Nurhayati, S. (2017). Keefektifan model Problem Based Learning untuk meningkatkan keterampilan proses sains siswa. Jurnal Inovasi Pendidikan Kimia, 11(1). Retrieved from https:/ / journal.unnes.ac.id/nju/index.php/JIPK/article/view/9714.

Ibrahim, M. M. (2014). Implementasi kurikulum 2013 (Rekonstruksi kompetsi, revolusi pembelajaran dan reformasi penilaian). Makassar: Alauddin University Press.

Illahi, T. A. R. (2018). Pengembangan multimedia interaktif pada pembelajaran materi jenis-jenis pekerjaan untuk meningkatkan kemampuan berpikir kritis. Jurnal Review Pendidikan Dasar: Jurnal Kajian Pendidikan dan Hasil Penelitian, 4(3), 826-835. http:/ / doi.org/10.26740/jrpd.v4n3.p826-835.

Irianto, H. A. (2010). Statistik konsep dasar, aplikasi, dan pengembangannya. Jakarta: Prenada Media.

Kadir, A. (2015). Dasar-dasar pendidikan. Kencana. Jakarta: Prenada Media.

Kaharuddin, A. (2019). Effect of problem based learning model on mathematical learning outcomes of 6th grade students of elementary school accredited 
$\mathrm{b}$ in kendari city. International Journal of Trends in Mathematics Education Research, 1(2). http:/ / doi.org/10.33122/ijtmer. v1i2.14.

Khoiriyah, A. J., \& Husamah, H. (2018). Problem-based learning: Creative thinking skills, problem-solving skills, and learning outcome of seventh grade students. JPBI (Jurnal Pendidikan Biologi Indonesia), 4(2), 151-160. https://doi.org/10.22219/jpbi.v4i2.5804.

Mudlofir, A., \& Rusydiyah, E. F. (2016). Desain pembelajaran inovatif dari teori ke praktik. Jakarta: PT Rajagrafindo Persada.

Mulyanto, H., Gunarhadi, G., \& Indriayu, M. (2018). The effect of problem based learning model on student mathematics learning outcomes viewed from critical thinking skills. International Journal of Educational Research Review, 3(2), 37-45. http:/ / doi.org/10.24331/ijere.408454.

Mustami, M. K., \& Irwansyah, M. (2015). Pengembangan lembar kerja peserta didik (LKPD) berorientasi pendekatan saintifik pada mata pelajaran biologi di SMA. Lentera Pendidikan: Jurnal Ilmu Tarbiyah dan Keguruan, 18(2), 236-247. https:/ / doi.org/10.24252/lp.2015v18n2a8.

Nuralam, N., \& Eliyana, E. (2017). Penerapan pendekatan saintifik terhadap kemampuan pemecahan masalah matematika di SMAN 1 Darul Imarah Aceh Besar. Jurnal Ilmiah Didaktika: Media Ilmiah Pendidikan dan Pengajaran, 18(1), 64-76. http:/ / doi.org/10.22373/jid.v18i1.3085.

Paloloang, M. F. B. (2014). Penerapan model problem based learning (PBL) untuk meningkatkan hasil belajar siswa pada materi panjang garis singgung persekutuan dua lingkaran di kelas VIII SMP Negeri 19 Palu. Jurnal Elektronik Pendidikan Matematika Tadulako,2(1). Retrieved from http://jurnal.untad.ac.id/jurnal/index.php/JEPMT/article/view /3232.

Rukmana, M., Jalmo, T., \& Yolida, B. (2013). Pengaruh model problem based learning (pbl) terhadap aktivitas dan hasil belajar siswa. Jurnal Bioterdidik: Wahana Ekspresi Ilmiah, 1(4). Retrieved from http://jurnal.fkip.unila. ac.id/index.php/JBT/article/view/1024.

Rusman, R. (2015). Pembelajaran tematik terpadu. Jakarta: Raja Grafindo Persada.

Sari, I. N., Wahyudi, W., \& Hendrias, H. (2017). Application of problem based learning model to learning outcomes of student in light matter in the class VIII SMP Negeri 1 Ledo kabupaten Bengkayang. Journal of Physics: Theories and Applications, 1(1), 75-82. http://doi.org/10.20961/ jphystheor-appl.v1i1.4720.

Sugiyono, P. (2015). Metode penelitian kombinasi. Bandung: Alfabeta.

Susanto, A. (2013). Teori belajar dan pembelajaran di sekolah dasar. Jakarta: Kencana.

Untayana, J. R., \& Harta, I. (2016). Pengembangan perangkat pembelajaran limit berbasis pendekatan saintifik berorientasi prestasi belajar dan kemampuan komunikasi matematika. Jurnal Riset Pendidikan Matematika, 3(1), 45-54. https://doi.org/10.21831/jrpm.v3i1.9683. 